\title{
NEW ZEALAND'S \\ WORKFORCE:
EVIDENCE OF UPSKILLING?
}

\author{
William S. Dillingham* \\ Labour Market Policy Group \\ Department of Labour \\ L3, Unisys House \\ Wellington
}

\begin{abstract}
In this paper, I investigate the prospect that there has been a general 'upskilling' in the New Zealand workforce. This research allows me to conclude several points. First, there is reason to believe that a general upskilling in the New Zealand workforce has occurred. Second, real incomes have been growing in the face of increasing supply, indicating strong, increasing relative demand for educated workers. Further, there is more to incomes than qualifications; to a tangible extent, the incomes of peers, regardless of qualifications, affect wages. Fourth, women are entering the labor force at a greater rate than men; significantly, this is true at the university end of the qualification spectrum. Finally, there is evidence to suggest a persistent, wide-spread disparity between the incomes of men and women, regardless of qualification, industry, and occupation.
\end{abstract}

\section{Introduction}

There is an increasingly common presumption of widespread skills shortages, especially at the upper end of the skills distribution. Common sense, and economic theory, would predict that skills-shortages would drive up wages; these relatively higher wages would attract new supply (through education and immigration). This process is, if it exists, could be called 'upskilling'. The purpose of this paper is to identify and, where possible, quantify this upskilling.

In the following, I am looking at one part of the labour market system: qualifications. I make the assumption that qualifications are a good proxy for skills. Thus, if there is a general and significant turn towards a 'high skilled, high tech, knowledge' economy, then there, reasonably, ought to be a sign of it in the data on qualifications.

Specifically, in this paper I address three themes. First, I look at the trend in qualifications across the three most recent census cycles to estimate whether there is a general upward trend in skill acquisition. Second, I discuss the relationship between qualifications and occupations, where the intersection is alternately median wages and the number/share of incumbents. Third, by combining the data from the four qualifications categories created, I construct a single variable with which I solve for growth in income, supply, and demand of 'relatively skilled' workers from 1991 to 2001 .
A opportune outcome from this analysis is the opportunity to compare men's qualifications and incomes to women's. It is not unexpected that there are differences in the types of skills acquired or the choice of occupation between the genders. But, this research allows me to isolate observationally equivalent (by qualification, occupation, and industry) individuals and compare their incomes. Thus, in each of the three sections below, I offer some observations on the differences and similarities between men and women.

This research allows me to make several tentative observations. There is reason to believe that a general upskilling in the New Zealand workforce has occurred. Higher skills, measured by higher qualifications, are associated with higher incomes; although this isn't always true in New Zealand. These real incomes have been growing in the face of increasing supply, indicating a strong relative demand for educated workers. Further, there is more to incomes than qualifications; to a tangible extent, the incomes of peers, regardless of qualifications, affect wages. Women are entering the labor force at a greater rate than men; significantly, this is true at the university end of the qualification spectrum. Finally, there is a persistent, wide-spread disparity between the incomes of men and women, regardless of qualification, industry, and occupation.

The paper is organized in the following manner. Section 1 presents census data on the incomes and numbers of fulltime workers by their qualifications. Qualifications are allocated to four exclusive groups: University, Other 
Post-School, High School, and Fifth-Form or Less. Section 2 uses the same information to construct several occupation categories. The criterion used for creating these exclusive categories is the density of the four formal education levels in each occupation. Section 3 uses the four qualification groups to construct a single variable for relatively higher skilled workers. This variable is used to shed light on the idea of 'upskilling' and its unfortunate shadow, 'skills shortage'. A final section brings together the various conclusions of the paper and offers some ideas for future work.

\section{Trends in Qualifications ${ }^{2}$}

An obvious starting point in an analysis of general upskilling is with income and employment. Changes in incomes and levels of employment (by occupation and qualification) tell us much about the labor market, or, at least, the short side of the labor market. Table 1 provides information on growth in median income by qualification. $^{3}$

Table 1: Real Median Income $e^{4}$ by Qualification ${ }^{5,6}$

\begin{tabular}{|l|c|c|c|r|r|}
\hline \multicolumn{1}{|c|}{ Qualification } & \multicolumn{1}{|c|}{$\mathbf{1 9 9 1}$} & \multicolumn{1}{|c|}{$\mathbf{1 9 9 6}$} & \multicolumn{1}{|c|}{$\mathbf{2 0 0 1}$} & $\begin{array}{l}\text { Growth } \\
(\mathbf{9 6 - 0 1 )}\end{array}$ & $\begin{array}{l}\text { Growth } \\
\mathbf{( 9 1 - 0 1 )}\end{array}$ \\
\hline University & $\$ 49,985$ & $\$ 47,955$ & $\$ 49,883$ & $4.0 \%$ & $-0.2 \%$ \\
\hline Other Post-Secondary & $\$ 34,175$ & $\$ 35,990$ & $\$ 37,394$ & $3.9 \%$ & $9.4 \%$ \\
\hline High School & $\$ 32,709$ & $\$ 33,050$ & $\$ 33,770$ & $2.2 \%$ & $3.2 \%$ \\
\hline 5th Form or Less & $\$ 26,939$ & $\$ 28,186$ & $\$ 29,201$ & $3.6 \%$ & $8.4 \%$ \\
\hline Total & $\$ 31,947$ & $\$ 32,371$ & $\$ 34,405$ & $6.3 \%$ & $7.7 \%$ \\
\hline
\end{tabular}

Source: Censuses of Population and Dwellings

There are a few things that become immediately clear from the table. First, as far as qualifications signal skills and productivity, the higher the qualification earned, the higher the likely remuneration received. Second, incomes growth was uneven among the categories, but jumped significantly at the bottom end over the decade. However, growth was more even across the categories during the second half of the decade and, in fact, slightly favored the top-end. The third notable point is, perhaps, the most striking: In the age of the purported high-skill boom, the real return to those with the highest qualifications stayed about the same between 1991 and 2001. However, there was solid growth at the top end during the second-half of the decade.
Using median wages can lead to some odd results. For example, whereas the over-the-decade growth in University wages was stagnant in Table 1, the components of this category (wage growth of male and female university graduates) show no sign of this stagnation in Table 2 . That is, wages for both men and women university graduates grew significantly, but their allocation among income bands was such that the combination left the 'total' median income unchanged. In other words, the real wages university graduates grew over the decade, and especially so from 1996 to 2001 and this growth suggests increasing demand. This latter point will be taken up in greater detail in section three.

Table 2: Median Income by Qualification by Gender ${ }^{7}$

\begin{tabular}{|c|c|c|c|c|c|c|}
\hline Qualification & Gender & 1991 & 1996 & 2001 & $\begin{array}{l}\text { Growth } \\
\text { (96-01) }\end{array}$ & $\begin{array}{l}\text { Growth } \\
(91-01)\end{array}$ \\
\hline \multirow{2}{*}{ University } & Male & $\$ 55,332$ & $\$ 54,101$ & $\$ 58,713$ & $8.5 \%$ & $6.1 \%$ \\
\hline & Female & $\$ 40,724$ & $\$ 39,610$ & $\$ 42,416$ & $7.1 \%$ & $4.2 \%$ \\
\hline \multirow{2}{*}{ Other Post-Secondary } & Male & $\$ 36,501$ & $\$ 38,552$ & $\$ 40,097$ & $4.0 \%$ & $9.9 \%$ \\
\hline & Female & $\$ 30,490$ & $\$ 31,928$ & $\$ 33,373$ & $4.5 \%$ & $9.5 \%$ \\
\hline \multirow{2}{*}{ High School } & Male & $\$ 36,499$ & $\$ 37,295$ & $\$ 36,945$ & $-0.9 \%$ & $1.2 \%$ \\
\hline & Female & $\$ 28,772$ & $\$ 29,396$ & $\$ 30,107$ & $2.4 \%$ & $4.6 \%$ \\
\hline \multirow{2}{*}{ 5th Form or Less } & Male & $\$ 29,524$ & $\$ 30,621$ & $\$ 31,709$ & $3.6 \%$ & $7.4 \%$ \\
\hline & Female & $\$ 22,725$ & $\$ 24,220$ & $\$ 25,870$ & $6.8 \%$ & $13.8 \%$ \\
\hline \multirow[b]{2}{*}{ Average } & Male & $\$ 34,635$ & $\$ 35,921$ & $\$ 37,103$ & $3.3 \%$ & $7.1 \%$ \\
\hline & Female & $\$ 27,383$ & $\$ 28,448$ & $\$ 30,482$ & $7.2 \%$ & $11.3 \%$ \\
\hline
\end{tabular}

Source: Censuses of Population and Dwellings

From Table 2, it's again clear that the higher the qualifications, the higher the expected income. But, the premium earned for higher qualifications is much greater for men than for women. Indeed, the 2001 pay step from
Other Post-Secondary to University for men was $\$ 18,600$, while, for women, the step was about $\$ 9,000$. Moreover, the spread of male earnings by qualification (University minus Fifth Form or Less) was $\$ 27,000$, versus $\$ 16,500$ 
for women, which is another way of saying that women's incomes are much more concentrated than men's.

Between 1991 and 2001, there was very strong income growth in the lowest qualification category, especially for women. Moreover, the growth rate was greater overall for women than men. The same pattern held between 1996 and 2001. But, the big, but not surprising, news is that the wage differential between men and women leaves much to be anticipated. While women earned 82 cents for each dollar earned by men overall - an increase of 3 cents from 1991 - they earned a mere 72 cents for each dollar earned by men at the University level - a decrease of nearly two cents since 1991. The literature on this yawn is extensive, much of it dedicated to 'explaining' away much - but never all - of the gap. ${ }^{8}$

Table 3: Income Ratios per Gender (Fifth-Form or Less Excluded)

\begin{tabular}{|l|l|c|c|c|}
\hline \multicolumn{1}{|c|}{ Qualification } & Gender & 1991 & 1996 & 2001 \\
\hline \multirow{4}{*}{ University } & Male & 1.87 & 1.77 & 1.85 \\
\cline { 2 - 5 } & Female & 1.79 & 1.64 & 1.64 \\
\cline { 2 - 5 } & Total & 1.86 & 1.70 & 1.71 \\
\hline \multirow{4}{*}{ Other Post-Secondary } & Male & 1.24 & 1.26 & 1.26 \\
\cline { 2 - 5 } & Female & 1.34 & 1.32 & 1.29 \\
\cline { 2 - 5 } & Total & 1.27 & 1.28 & 1.28 \\
\hline \multirow{5}{*}{ Average } & Male & 1.24 & 1.22 & 1.17 \\
\cline { 2 - 5 } & Female & 1.27 & 1.21 & 1.16 \\
\cline { 2 - 5 } & Total & 1.21 & 1.17 & 1.16 \\
\hline & Male & 1.17 & 1.17 & 1.17 \\
\cline { 2 - 5 } & Female & 1.20 & 1.17 & 1.18 \\
\cline { 2 - 5 } & Total & 1.19 & 1.15 & 1.18 \\
\hline
\end{tabular}

Source: Censuses of Population and Dwellings
The next table looks at wages for each qualification category relative to the (excluded) Fifth-Form or Less category (men are compared to men; women, women).

Table 3 reveals that wages by qualification became more concentrated, or less unequal, over the decade. As the previous tables revealed, this is greatly due to the significant increases in incomes going to full-time employees with fifth form (or less) education. In other words, even though wages at the top-end increased for both men and women, wages at the bottom end increased by more, thus reducing the differential. There was one exception to this outcome: The earnings differential for men between Fifth-Form or Less and Other PostSecondary qualifications increased. (Likewise, the premium for male university graduates jumped significantly after 1996). Nevertheless, from this perspective, the high-skill wage premium has fallen somewhat. And, if true, the argument regarding a shortage of higher skilled workers seems to stumble.

I now turn to changes in employment by qualification, which, when combined with wage data, will allow me to draw some tentative conclusions. Table 4 presents data on total, male, and female employment by qualification.

Table 4: Employment by Qualification and Gender

\begin{tabular}{|c|c|c|c|c|c|}
\hline Qualification & Gender & 1991 & 1996 & 2001 & $\begin{array}{l}\text { Growth } \\
(96-01)\end{array}$ \\
\hline \multirow{3}{*}{ University } & Male & 69,171 & 89,628 & 107,928 & $20.4 \%$ \\
\hline & Female & 32,007 & 50,490 & 79,122 & $56.7 \%$ \\
\hline & Total & 101,175 & 140,121 & 187,053 & $33.5 \%$ \\
\hline \multirow{3}{*}{ Other Post-Secondary } & Male & 257,274 & 180,759 & 179,253 & $-0.8 \%$ \\
\hline & Female & 120,411 & 95,424 & 106,740 & $11.9 \%$ \\
\hline & Total & 377,682 & 276,183 & 285,990 & $3.6 \%$ \\
\hline \multirow{3}{*}{ High School } & Male & 60,099 & 85,725 & 134,325 & $56.7 \%$ \\
\hline & Female & 36,762 & 59,535 & 94,074 & $58.0 \%$ \\
\hline & Total & 96,861 & 145,263 & 228,399 & $57.2 \%$ \\
\hline \multirow{3}{*}{ 5th Form or Less } & Male & 226,404 & 251,532 & 249,681 & $-0.7 \%$ \\
\hline & Female & 131,532 & 152,889 & 150,351 & $-1.7 \%$ \\
\hline & Total & 357,933 & 404,421 & 400,032 & $-1.1 \%$ \\
\hline \multirow{3}{*}{ Total } & Male & 629,850 & 683,502 & 727,998 & $6.5 \%$ \\
\hline & Female & 334,065 & 403,017 & 458,271 & $13.7 \%$ \\
\hline & Total & 963,915 & $1,086,516$ & $1,186,269$ & $9.2 \%$ \\
\hline
\end{tabular}

Source: Censuses of Population and Dwellings 
Bearing in mind the corresponding details from the income tables above, this table fleshes out some interesting suppositions. First, I am struck by the simultaneous jump in full-time employment of women with university degrees - up nearly 60 percent from 1996 (and 150 percent over the decade) - and that same group's (median) real wages - up by over 7 percent. Together, this implies that demand for women with university qualifications outstripped supply by a significant amount. ${ }^{9}$ Second and more generally, the demand for full-time labor must have exceeded the supply of workers willing to work full-time, since employment moved ahead by just over 33 percent while wages climbed 4 percent.

Next, there was a stark difference in outcomes at the Other Post-Secondary level with male employment holding steady while female employment jumping 12 percent. Nevertheless, wages for both men and women in this category moved ahead by about 4 percent. But the real eyebrow-raising outcome is at the High School level: Both male and female full-time employment grew by nearly 60 percent. However, only women's wages increased in the category.
Finally, it is also reasonable to assume that because of such strong growth in top-end employment growth, coupled with solid growth in top-end wages, that there has been increasing demand for higher skilled workers, but no indication that this demand has exceeded or been at the expense of lower-skilled work. I estimate this increase in demand later in the paper.

\section{Heterogeneity of Qualifications and Occupations}

In this section, I stratify occupations according to the qualifications of incumbents. The data in this section are limited to the 2001 Census. By applying qualification density criteria (admittedly derived in a somewhat arbitrary fashion) to 3-digit occupations, I have created several categories of occupations. ${ }^{10}$ Due to space considerations, I limit the discussion to just a few such categories.

Table 5: Occupation Groupings and Income ${ }^{11}$ by Incumbent Qualification

\begin{tabular}{|c|c|c|c|c|c|c|c|}
\hline \multirow{3}{*}{ 3-digit Occupation } & \multirow{2}{*}{\multicolumn{4}{|c|}{ Percentage Concentrations }} & \multirow{2}{*}{\multicolumn{3}{|c|}{ Income Deciles }} \\
\hline & & & & & & & \\
\hline & Univ & $\begin{array}{l}\text { Other Post- } \\
\text { Secondary }\end{array}$ & $\begin{array}{c}\text { High } \\
\text { School }\end{array}$ & $\begin{array}{c}\text { Fifth Form } \\
\text { or Less } \\
\end{array}$ & 10th & Median & 90th \\
\hline University Qual Occupations & & & & & $\$ 29,549$ & $\$ 56,722$ & $\$ 100,001$ \\
\hline Legal Professionals & 88.3 & 3.9 & 4.7 & 3 & $\$ 29,562$ & $\$ 68,963$ & $\$ 100,001$ \\
\hline Health Professionals (Except Nursing) & 84.4 & 9 & 5.7 & 0.9 & $\$ 35,677$ & $\$ 80,547$ & $\$ 100,001$ \\
\hline Mathematicians, Statisticians Professionals & 78 & 9.1 & 10.3 & 2.6 & $\$ 32,389$ & $\$ 53,601$ & $\$ 100,001$ \\
\hline Physicists, Chemists Professionals & 75.8 & 14.1 & 6.9 & 3.2 & $\$ 29,548$ & $\$ 52,327$ & $\$ 90,005$ \\
\hline Tertiary Teaching Professionals & 71.2 & 20.5 & 5.4 & 2.9 & $\$ 27,701$ & $\$ 53,831$ & $\$ 88,841$ \\
\hline Secondary Teaching Professionals & 70.4 & 25.8 & 3 & 0.8 & $\$ 30,485$ & $\$ 52,288$ & $\$ 67,253$ \\
\hline Social and Related Science Professionals & 65.9 & 20.3 & 8.5 & 5.4 & $\$ 24,229$ & $\$ 46,905$ & $\$ 86,925$ \\
\hline Other Post-Secondary Qual Occupations & & & & & $\$ 20,722$ & $\$ 36,743$ & $\$ 63,634$ \\
\hline Nursing Associate Professionals & 5.4 & 77.7 & 4.2 & 12.7 & $\$ 17,469$ & $\$ 28,693$ & $\$ 42,859$ \\
\hline Electricians & 1 & 77.1 & 9.9 & 12 & $\$ 21,545$ & $\$ 38,124$ & $\$ 65,154$ \\
\hline \multicolumn{8}{|l|}{ High School Qual (Only) Occupations } \\
\hline \multicolumn{8}{|l|}{ Nil } \\
\hline Fifth-Form or Less Qual Occupations & & & & & "\$12,879 & $\$ 27,357$ & $\$ 47,286$ \\
\hline Agricultural, Earthmoving Equip't Operators & 1.2 & 13 & 12.3 & 73.4 & $\$ 15,524$ & $\$ 30,973$ & $\$ 53,681$ \\
\hline Railway Engine Drivers and Related Workers & 0.6 & 11.6 & 15.8 & 72 & $\$ 26,667$ & $\$ 52,783$ & $\$ 67,160$ \\
\hline Motor Vehicle Drivers & 1.6 & 11.8 & 14.6 & 71.9 & $\$ 15,294$ & $\$ 29,720$ & $\$ 48,500$ \\
\hline Leather and Related Products Processors & 1.8 & 12.5 & 15.5 & 70.1 & $\$ 16,206$ & $\$ 28,305$ & $\$ 43,378$ \\
\hline Refuse Collectors and Related Labourers & 1.6 & 14.2 & 14.2 & 70 & $\$ 10,444$ & $\$ 26,574$ & $\$ 50,251$ \\
\hline Food and Related Machine Operators & 2 & 12.8 & 16.1 & 69.2 & $\$ 15,078$ & $\$ 28,150$ & $\$ 45,663$ \\
\hline Labourers & 2.2 & 12.7 & 16.8 & 68.3 & $\$ 10,752$ & $\$ 25,077$ & $\$ 42,464$ \\
\hline Textile Products Machine Operators & 2.1 & 8.5 & 22.2 & 67.2 & $\$ 10,405$ & $\$ 21,080$ & $\$ 36,204$ \\
\hline Packers and Freight Handlers & 2.3 & 11.2 & 20 & 66.6 & $\$ 10,890$ & $\$ 25,483$ & $\$ 46,121$ \\
\hline Wood-Processing and Related Operators & 2.2 & 18 & 14.1 & 65.7 & $\$ 16,907$ & $\$ 33,030$ & $\$ 67,117$ \\
\hline Univ/Other Post-School Qual Occupations & & & & & $\$ 18,229$ & $\$ 37,171$ & $\$ 61,201$ \\
\hline Special Education Teaching Professionals & 55.7 & 32.6 & 6.8 & 4.9 & $\$ 17,286$ & $\$ 40,213$ & $\$ 63,683$ \\
\hline Archivists, Librarians Professionals & 40.8 & 35 & 13.5 & 10.8 & $\$ 18,836$ & $\$ 35,806$ & $\$ 56,698$ \\
\hline
\end{tabular}

Source: Censuses of Population and Dwellings (2001) 
Although this classification scheme is arbitrary, its utility is seen in Table 5. At one extreme nearly 90 percent of Legal Professionals possess a university degree; at the other extreme, about three-quarters of Agricultural and Earthmoving Equipment Operators do not possess more than a fifth form certificate. The former category requires a high degree of formal, classroom training; the latter requires little formal training, but may offer special or onthe-job training.

The table serves to underscore the point made earlier: While there are highly remunerated occupations that do not require advanced degrees, in the main, the higher the qualification obtained, the higher the income received. This is as true for the $10^{\text {th }}$ and $90^{\text {th }}$ percentiles as it is for the median. The only occupation that appears to garner earnings well above equally 'qualified' occupations is the highly unionised, if skilled, Railway Engine Drivers.

Interestingly, there is not a single occupation that is dominated by high-school (only) graduates - in spite of the large numbers of employees with the qualification. From this, it appears as though high school does not provide many marketable skills over and above the fifth form level and around which an occupation has built its worker base. In other words, just about any job that one could do with a high school diploma, one could just as easily do with a lesser qualification.

It's worth highlighting the fact that no occupation (at the three-digit level) requires any single type of degree; all are mixes to some extent. This is trivially true for what I have called 'mixed type' occupations, but it is also true for 'pure type' occupations. For example, Packers and Freight Handlers are classified as a Fifth Form or Less occupation, but nearly 1 out of 3 incumbents have more than just a fifth form certificate. Indeed, 14 percent have some type of tertiary degree when this is clearly unnecessary for the tasks required.

This last point provokes the question about whether those with higher degrees who work in occupations that do not 'require' those degrees earn more than their (formally) less-educated colleagues. For example, the median wage over all Fifth Form or Less occupations is $\$ 27,357$. Is this an accurate description of the earnings of universitydegreed jobholders as well as high-school non-finishers?

Table 6 presents the breakdown of incomes by qualification within each occupation classification. The table also provides income data by gender. Further, the table provides the ratio of the row median to the 'total' median for that classification. In the interest of conserving space, classifications are limited to just four. The rows associated with the first classification, Total All Occupations, rehearse data provided in earlier tables.

This table shows that a university-educated female earns about $\$ 52,500$ in university qualification occupations, but earns much less than one-half of that, or about $\$ 21,200$, in the lowest occupation category. A male high-school nonfinisher earns about $\$ 29,300$ in this lowest qualificationbased occupation, but earns nearly $\$ 37,000$ in university qualification occupations. ${ }^{12}$ In other words, a university degree is necessary to get a high-paying job, but certainly not sufficient.

Table 6: Income by Qualification and Gender per Classification

\begin{tabular}{|c|c|c|c|c|c|c|c|c|c|c|}
\hline \multirow[b]{2}{*}{ Classification } & \multirow[b]{2}{*}{ Qualification } & \multicolumn{3}{|c|}{ Total } & \multicolumn{3}{|c|}{ Male } & \multicolumn{3}{|c|}{ Female } \\
\hline & & & edian & Ratio & & edian & Ratio & & edian & Ratio \\
\hline \multirow{5}{*}{$\begin{array}{l}\text { Total All } \\
\text { Occupations }\end{array}$} & University Qualification & $\$$ & 49,883 & 1.45 & $\$$ & 58,713 & 1.58 & $\$$ & 42,416 & 1.39 \\
\hline & Other Post-Secondary Qualification & $\$$ & 37,394 & 1.09 & $\$$ & 40,097 & 1.08 & $\$$ & 33,373 & 1.09 \\
\hline & High School & $\$$ & 33,770 & 0.98 & $\$$ & 36,945 & 1.00 & $\$$ & 30,107 & 0.99 \\
\hline & Fifth Form or Less & $\$$ & 29,201 & 0.85 & $\$$ & 31,709 & 0.85 & $\$$ & 25,870 & 0.85 \\
\hline & Total & $\$$ & 34,405 & 1.00 & $\$$ & 37,103 & 1.00 & $\$$ & 30,482 & 1.00 \\
\hline \multirow{5}{*}{$\begin{array}{l}\text { Total University } \\
\text { Qual Occupations }\end{array}$} & University Qualification & $\$$ & 60,037 & 1.06 & $\$$ & 66,365 & 1.06 & $\$$ & 52,489 & 1.06 \\
\hline & Other Post-Secondary Qualification & $\$$ & 47,879 & 0.84 & $\$$ & 52,428 & 0.83 & $\$$ & 45,383 & 0.91 \\
\hline & High School & $\$$ & 48,903 & 0.86 & $\$$ & 55,473 & 0.88 & $\$$ & 42,391 & 0.85 \\
\hline & Fifth Form or Less & $\$$ & 34,489 & 0.61 & $\$$ & 36,700 & 0.58 & $\$$ & 31,251 & 0.63 \\
\hline & Total & $\$$ & 56,722 & 1.00 & $\$$ & 62,850 & 1.00 & $\$$ & 49,707 & 1.00 \\
\hline \multirow{5}{*}{$\begin{array}{l}\text { Other Post- } \\
\text { Secondary Qual } \\
\text { Occupations }\end{array}$} & University Qualification & $\$$ & 36,556 & 0.99 & $\$$ & 36,154 & 0.95 & $\$$ & 35,625 & 1.26 \\
\hline & Other Post-Secondary Qualification & $\$$ & 37,924 & 1.03 & $\$$ & 39,526 & 1.03 & $\$$ & 28,257 & 1.00 \\
\hline & High School & $\$$ & 33,848 & 0.92 & $\$$ & 34,369 & 0.90 & $\$$ & 31,853 & 1.12 \\
\hline & Fifth Form or Less & $\$$ & 32,419 & 0.88 & $\$$ & 34,220 & 0.89 & $\$$ & 26,980 & 0.95 \\
\hline & Total & $\$$ & 36,743 & 1.00 & $\$$ & 38,236 & 1.00 & $\$$ & 28,318 & 1.00 \\
\hline \multirow{5}{*}{$\begin{array}{l}\text { Total Fifth-Form or } \\
\text { Less Qual } \\
\text { Occupations }\end{array}$} & University Qualification & $\$$ & 24,931 & 0.91 & $\$$ & 26,049 & 0.89 & $\$$ & 21,213 & 1.03 \\
\hline & Other Post-Secondary Qualification & $\$$ & 29,853 & 1.09 & $\$$ & 31,786 & 1.09 & $\$$ & 19,875 & 0.97 \\
\hline & High School & $\$$ & 26,491 & 0.97 & $\$$ & 28,554 & 0.98 & $\$$ & 20,827 & 1.02 \\
\hline & Fifth Form or Less & $\$$ & 27,425 & 1.00 & $\$$ & 29,310 & 1.00 & $\$$ & 20,617 & 1.00 \\
\hline & Total & $\$$ & 27,357 & 1.00 & s & 29,260 & 1.00 & $\$$ & 20,519 & 1.00 \\
\hline
\end{tabular}

Source: Censuses of Population and Dwellings (2001) 
Further, for men, possessing a university degree does not necessarily guarantee the highest income even within the same occupation classification. For example, a universitydegreed male employee in the Fifth Form or Less classification earns about 11 cents less per dollar of income than a high-school non-completer and 21 cents per dollar less than someone with some other postsecondary education. This would seem to imply that, to some extent, education is not simply a sorting process or a signalling device. ${ }^{13}$ The same doesn't necessarily hold true for women. For each occupation category, the income of the university-educated women is above that for lesser-educated peers.

Thus, there is more affecting income in any given classification than just the effect of that qualification group's pay range. A university graduate will earn considerably more in university-type occupations than in non-university-type occupations (in general, education matters), but may earn less than his less-well-educated counterparts in these non-university-type occupations (more specifically, education isn't the whole story). And for any given qualification, expected income increases with the incomes of peers (i.e., those within the same occupation).

I noted earlier that women earned about 82 cents for every dollar earned by men. This was an aggregate figure. Thus, the 18-cent difference could result from the choice of occupation, or composition effects, per qualification. In other words, (to use an extreme example) maybe the differences in income results from university-educated women working as librarians while university-educated men work as lawyers.

The following table allows us to compare 'like with like' by breaking down single occupations ( 3 digit) for men and women by qualifications and median earnings. I've simply chosen three occupations (representing different types of work and expectations) to compare, but the pattern holds for nearly every 3 -digit occupation. ${ }^{14}$

Table 7: Median Income by Qualification by Gender

\begin{tabular}{|c|c|c|c|c|c|}
\hline Occupation & Qualification & & Iale & & nale \\
\hline \multirow{5}{*}{ Legal Professionals } & University Qualification & & 95,349 & $\$$ & 52,658 \\
\hline & Other Post-Secondary Qualification & $\$$ & 47,917 & $\$$ & 39,167 \\
\hline & High School & $\$$ & 51,819 & $\$$ & 38,445 \\
\hline & Fifth Form or Less & $\$$ & 38,621 & $\$$ & 33,368 \\
\hline & Total & $\$$ & 89,849 & $\$$ & 48,496 \\
\hline \multirow{5}{*}{ Religious Professionals } & University Qualification & $\$$ & 33,742 & $\$$ & 31,462 \\
\hline & Other Post-Secondary Qualification & $\$$ & 30,783 & $\$$ & 22,116 \\
\hline & High School & $\$$ & 22,693 & $\$$ & 14,436 \\
\hline & Fifth Form or Less & $\$$ & 24,197 & $\$$ & 13,500 \\
\hline & Total & $\$$ & 31,134 & $\$$ & 20,663 \\
\hline \multirow{5}{*}{ Legislators } & University Qualification & $\$$ & 79,707 & $\$$ & 66,364 \\
\hline & Other Post-Secondary Qualification & $\$$ & 65,000 & $\$$ & 43,001 \\
\hline & High School & $\$$ & 56,667 & $S$ & 46,429 \\
\hline & Fifth Form or Less & $\$$ & 48,637 & $\$$ & 35,001 \\
\hline & Total & $\$$ & 62,882 & $\$$ & 46,667 \\
\hline
\end{tabular}

Source: Censuses of Population and Dwellings (2001)

For the occupations chosen the difference in incomes is greater at this level of comparability. In fact, in the above table, women earn an average of 72 cents on the male dollar. The legal profession offers a stark contrast in earnings: Women earn just a bit more than half of what men earn. At the other extreme, in the religious profession, university educated women earn about 93 cents for every dollar earned by men. In between these extremes lie the legislators' incomes. Even though a higher percentage of female legislators possess a university degree $(34 \%$, versus $30 \%)$, these women take home about 83 cents for each dollar paid to their male colleagues.
However, these results, in and of themselves, do not make the case for discrimination; the table's results do not take account of other factors that we would expect to influence the wages of men and women, like relevant experience and the effects of broken careers. In fact, if it shows anything, then the above table shows that even in the highly structured employment environment of Legislators, a pay gap persists, which indicates that other, notoriously-hard-to-measure factors are the drivers behind persistent wage gaps. ${ }^{15}$

An occupation describes the work that is done, irrespective of what is produced and this omission may 
matter. Thus, another way of looking at the data is by the allocation of qualifications among industry groups. Admittedly, the level of industry detail in Table 8 isn't particularly informative, but it does help to highlight a couple of things. As with other tables, I am forced to limit the exposition because of concerns about length.

Table 8: Median Income by Industry for Two Qualifications

\begin{tabular}{|l|r|r|r|r|}
\cline { 2 - 5 } \multicolumn{1}{c|}{} & \multicolumn{2}{c|}{ University } & \multicolumn{2}{c|}{ Fifth Form or Less } \\
\cline { 2 - 5 } \multicolumn{1}{c|}{ Total All Industries } & Median & \multicolumn{1}{c|}{ Share } & \multicolumn{1}{c|}{ Median } & Share \\
\hline A Agriculture, Forestry and Fishing & $\$ 49,883$ & $100 \%$ & $\$ 29,201$ & $100 \%$ \\
\hline B Mining & $\$ 35,367$ & $3 \%$ & $\$ 27,207$ & $13 \%$ \\
\hline C Manufacturing & $\$ 77,374$ & $0 \%$ & $\$ 36,926$ & $0 \%$ \\
\hline D Electricity, Gas and Water Supply & $\$ 49,089$ & $7 \%$ & $\$ 29,853$ & $20 \%$ \\
\hline E Construction & $\$ 68,095$ & $1 \%$ & $\$ 36,195$ & $0 \%$ \\
\hline F Wholesale Trade & $\$ 45,108$ & $1 \%$ & $\$ 31,294$ & $8 \%$ \\
\hline G Retail Trade & $\$ 54,318$ & $5 \%$ & $\$ 33,374$ & $8 \%$ \\
\hline H Accommodation, Cafes and Restaurants & $\$ 32,745$ & $4 \%$ & $\$ 25,589$ & $12 \%$ \\
\hline I Transport and Storage & $\$ 29,880$ & $2 \%$ & $\$ 22,242$ & $3 \%$ \\
\hline J Communication Services & $\$ 41,695$ & $2 \%$ & $\$ 33,621$ & $6 \%$ \\
\hline K Finance and Insurance & $\$ 60,891$ & $1 \%$ & $\$ 32,502$ & $1 \%$ \\
\hline L Property and Business Services & $\$ 62,643$ & $5 \%$ & $\$ 36,997$ & $2 \%$ \\
\hline M Government Administration and Defence & $\$ 51,927$ & $8 \%$ & $\$ 34,368$ & $3 \%$ \\
\hline N Education & $\$ 49,864$ & $20 \%$ & $\$ 25,192$ & $2 \%$ \\
\hline O Health and Community Services & $\$ 48,407$ & $12 \%$ & $\$ 24,176$ & $4 \%$ \\
\hline P Cultural and Recreational Services & $\$ 38,828$ & $3 \%$ & $\$ 28,596$ & $2 \%$ \\
\hline Q Personal and other Services & $\$ 41,338$ & $3 \%$ & $\$ 29,711$ & $3 \%$ \\
\hline R Not Elsewhere Included & $\$ 36,408$ & $1 \%$ & $\$ 22,413$ & $4 \%$ \\
\hline
\end{tabular}

Source: Censuses of Population and Dwellings (2001)

Note that the education premium - the difference in earnings between the two education categories - for some industries is quite small, especially relative to the opportunity costs associated with obtaining a university education. Where there is a reliance on expert and specific knowledge, the premium is much higher. Thus, for example, I am relieved not to find much of a difference in earnings in the retail trade group. However, I expected, and find, a big difference in finance and business.

The table also provides information on qualification concentrations among industry groups. It is not surprising to see that university graduates are concentrated in the more cerebral industry groups; likewise, there is a high concentration of fifth-formers (or less) in the more manual industries.

Table 9 breaks the information down by gender and limits the qualification to just one: university. University graduates are distributed among the industries in broadly similar patterns, with concentrations in the tertiary industries. Men, however, are more highly concentrated in business, whereas women are more concentrated in education and health.
Tables 8 and 9 (see next page) don't exhaust the possibilities of analysis with this type of data; perhaps occupational choice is informative. Table 10 , on the next page, drills down one more level by directly comparing, across industry groups, university graduates working within the occupation of Computer Professionals.

Of all such incumbents, about half are working in business services and about one out of ten are in wholesale trade. Women are slightly more concentrated than men in the finance and government industries.

Given the new economy-like attributes that are tied up with computer-related, knowledge-intensive fields, there is an assumption of greater equality in pay (perhaps because of the truly androgynous nature of computerrelated skills or knowledge). And, this actually appears to be true: A woman's expected income as a university educated computer professional is nearly 85 percent of a man's - which, it must be stated, is 13 cents better than the overall average for university graduates. In fact, in two cases the women's median income is actually more than men's - granted, one is a residual category. ${ }^{16}$ 
Table 9: Median Income by Industry and University Qualification

\begin{tabular}{|c|c|c|c|c|c|c|}
\hline \multirow[b]{2}{*}{ University Qualifications } & \multicolumn{3}{|c|}{ Male } & \multicolumn{3}{|c|}{ Female } \\
\hline & & ian & Share & & ian & Share \\
\hline Total All Industries & $\$$ & 58,713 & $100 \%$ & $\$$ & 42,416 & $100 \%$ \\
\hline A Agriculture, Forestry and Fishing & $\$$ & 38,537 & $4 \%$ & $\$$ & 28,815 & $2 \%$ \\
\hline B Mining & $\$$ & 81,667 & $0 \%$ & $\$$ & 57,001 & $0 \%$ \\
\hline C Manufacturing & $\$$ & 55,303 & $8 \%$ & $\$$ & 39,040 & $5 \%$ \\
\hline D Electricity, Gas and Water Supply & $\$$ & 75,600 & $1 \%$ & $\$$ & 47,283 & $0 \%$ \\
\hline E Construction & $\$$ & 46,858 & $2 \%$ & $\$$ & 36,205 & $0 \%$ \\
\hline F Wholesale Trade & $\$$ & 60,537 & $6 \%$ & $\$$ & 43,411 & $3 \%$ \\
\hline G Retail Trade & $\$$ & 35,991 & $4 \%$ & $\$$ & 28,955 & $3 \%$ \\
\hline H Accommodation, Cafes and Restaurants & $\$$ & 33,200 & $1 \%$ & $\$$ & 27,515 & $2 \%$ \\
\hline I Transport and Storage & $\$$ & 48,027 & $2 \%$ & $\$$ & 36,267 & $2 \%$ \\
\hline J Communication Services & $\$$ & 68,382 & $1 \%$ & $\$$ & 49,530 & $1 \%$ \\
\hline K Finance and Insurance & $\$$ & 77,097 & $5 \%$ & $\$$ & 44,492 & $4 \%$ \\
\hline L Property and Business Services & $\$$ & 66,273 & $29 \%$ & $\$$ & 45,866 & $17 \%$ \\
\hline M Government Administration and Defence & $\$$ & 59,521 & $7 \%$ & $\$$ & 45,145 & $8 \%$ \\
\hline N Education & $\$$ & 55,986 & $14 \%$ & $\$$ & 45,687 & $28 \%$ \\
\hline O Health and Community Services & $\$$ & 76,287 & $9 \%$ & $\$$ & 40,131 & $17 \%$ \\
\hline P Cultural and Recreational Services & $\$$ & 42,687 & $2 \%$ & $\$$ & 36,133 & $3 \%$ \\
\hline Q Personal and other Services & $\$$ & 43,135 & $3 \%$ & $\$$ & 38,889 & $3 \%$ \\
\hline R Not Elsewhere Included & $\$$ & 41,398 & $1 \%$ & $\$$ & 30,268 & $1 \%$ \\
\hline
\end{tabular}

Source: Censuses of Population and Dwellings (2001)

Table 10: Median Income by Industry for Univ Grad Computer Professionals

\begin{tabular}{|c|c|c|c|c|c|c|c|}
\hline & \multicolumn{2}{|c|}{ Total } & \multicolumn{2}{|c|}{ Male } & \multicolumn{3}{|c|}{ Female } \\
\hline & Median & Share & Median & Share & & dian & Share \\
\hline Total All Industries & $\$ 56,610$ & $100 \%$ & $\$ 59,277$ & $100 \%$ & & 47,824 & $100 \%$ \\
\hline A Agriculture, Forestry and Fishing & $\$ 51,251$ & $1 \%$ & $\$ 51,539$ & $1 \%$ & $\$$ & 50,000 & $1 \%$ \\
\hline B Mining & $\$ 90,000$ & $0 \%$ & $\$ 95,000$ & $0 \%$ & $\$$ & 45,001 & $0 \%$ \\
\hline C Manufacturing & $\$ 54,461$ & $7 \%$ & $\$ \quad 56,667$ & $7 \%$ & $\$$ & 43,572 & $5 \%$ \\
\hline D Electricity, Gas and Water Supply & $\$ 60,385$ & $1 \%$ & $\$ 63,913$ & $1 \%$ & $\$$ & 45,001 & $1 \%$ \\
\hline E Construction & $\$ 44,546$ & $1 \%$ & $\$ \quad 45,556$ & $1 \%$ & $\$$ & 40,000 & $0 \%$ \\
\hline F Wholesale Trade & $\$ 57,513$ & $10 \%$ & $\$ \quad 59,299$ & $11 \%$ & $\$$ & 48,261 & $7 \%$ \\
\hline G Retail Trade & $\$ 47,250$ & $2 \%$ & $\$ 49,706$ & $2 \%$ & $\$$ & 36,000 & $2 \%$ \\
\hline H Accommodation, Cafes and Restaurants & $\$ 44,167$ & $0 \%$ & $\$ 48,000$ & $0 \%$ & $\$$ & 35,001 & $1 \%$ \\
\hline I Transport and Storage & $\$ 57,144$ & $1 \%$ & $\$ 56,001$ & $1 \%$ & $\$$ & 60,001 & $1 \%$ \\
\hline J Communication Services & $\$ 62,299$ & $4 \%$ & $\$ 65,082$ & $4 \%$ & $\$$ & 55,770 & $5 \%$ \\
\hline K Finance and Insurance & $\$ 63,629$ & $6 \%$ & $\$ 65,898$ & $5 \%$ & $\$$ & 58,572 & $9 \%$ \\
\hline L Property and Business Services & $\$ 59,240$ & $51 \%$ & $\$ 61,691$ & $53 \%$ & $\$$ & 49,587 & $44 \%$ \\
\hline M Government Administration and Defence & $\$ 51,792$ & $6 \%$ & $\$ 56,237$ & $5 \%$ & $\$$ & 45,278 & $10 \%$ \\
\hline N Education & $\$ 43,029$ & $4 \%$ & $\$ 45,268$ & $4 \%$ & $\$$ & 37,037 & $6 \%$ \\
\hline O Health and Community Services & $\$ 46,806$ & $2 \%$ & $\$ 48,421$ & $2 \%$ & $\$$ & 45,001 & $4 \%$ \\
\hline P Cultural and Recreational Services & $\$ 47,693$ & $1 \%$ & $\$ 53,334$ & $1 \%$ & $\$$ & 40,000 & $1 \%$ \\
\hline Q Personal and other Services & $\$ 48,500$ & $1 \%$ & \$ 53,334 & $1 \%$ & $\$$ & 45,001 & $2 \%$ \\
\hline R Not Elscwhere Included & $\$ 45,001$ & $1 \%$ & $\$ 43,334$ & $1 \%$ & $\$$ & 47,500 & $1 \%$ \\
\hline
\end{tabular}

Source: Censuses of Population and Dwellings (2001) 


\section{Changing Demand for Higher-Skilled Workers}

Above, I made several assertions regarding the demand for high-skilled workers. I also proposed that the demand for high-skilled women might be different than the demand for high-skilled men. In this section, I test these ideas.
It's informative to look at the changing shares of employment by qualification. Table 11 shows employment share by qualification by gender for the three most recent censuses. While University and High School employment shares increased (especially the latter), Other Post-Secondary and Fifth Form or Less employment shares dropped (the former, significantly). This seems to provide us with a mixed signal as to whether there was a significant upskilling in the workforce.

Table 11: Education Distribution by Gender

\begin{tabular}{|c|c|c|c|c|c|}
\hline Gender & Year & University & $\begin{array}{l}\text { Other Post- } \\
\text { Secondary }\end{array}$ & $\begin{array}{l}\text { High } \\
\text { School }\end{array}$ & $\begin{array}{c}\text { Fifth Form or } \\
\text { Less }\end{array}$ \\
\hline \multirow[t]{3}{*}{ Male } & 1991 & $11 \%$ & $41 \%$ & $10 \%$ & $36 \%$ \\
\hline & 1996 & $13 \%$ & $26 \%$ & $13 \%$ & $37 \%$ \\
\hline & 2001 & $15 \%$ & $25 \%$ & $18 \%$ & $34 \%$ \\
\hline \multirow[t]{3}{*}{ Female } & 1991 & $10 \%$ & $36 \%$ & $11 \%$ & $39 \%$ \\
\hline & 1996 & $13 \%$ & $24 \%$ & $15 \%$ & $38 \%$ \\
\hline & 2001 & $17 \%$ & $23 \%$ & $21 \%$ & $33 \%$ \\
\hline \multirow[t]{3}{*}{ Total } & 1991 & $10 \%$ & $39 \%$ & $10 \%$ & $37 \%$ \\
\hline & 1996 & $13 \%$ & $25 \%$ & $13 \%$ & $37 \%$ \\
\hline & 2001 & $16 \%$ & $24 \%$ & $19 \%$ & $34 \%$ \\
\hline
\end{tabular}

Source: Censuses of Population and Dwellings

To get around this, I have constructed a single variable from the four qualifications: relative skilled labor. The variable is constructed based on the assumption that the dividing line falls in the Other Post-Secondary qualification range in such a way that one-half of the group is considered higher skilled and one-half lower skilled. This assumes that one-half of Other PostSecondary workers are one-for-one substitutes for High School and Fifth Form or Less workers. It also implies that the other half of Other Post-Secondary workers are one-for-one substitutes for University graduates. ${ }^{17}$ But, once allocated to their respective halves, those with Other Post-Secondary are not one-to-one substitutes for one another. ${ }^{18}$

The objective is to construct a very simply model of the $\mathrm{NZ}$ labor market in order to estimate the relative importance of shifts in supply and demand of labor on changes in earnings from 1991 to 1996 to 2001. Assuming full employment, the estimated model is $S=D W^{\sigma}$, which can be simplified to:

$$
\frac{\Delta D}{D}=\sigma \frac{\Delta W}{W}+\frac{\Delta S}{S}, \text { where }
$$

$\mathrm{D}$ is relative demand, $\mathrm{W}$ is relative wage, and $\mathrm{S}$ is relative supply of skilled labor; sigma represents the elasticity of substitution between skilled and unskilled labor. ${ }^{19}$ Since I can derive $\mathrm{W}$ and $\mathrm{S}$ from the census data, I solve for $\mathrm{D}$.
Thus, I am able to estimate how much of the changes in wages have been the result of increasing demand.

Table 12 displays the results. Between 1991 and 1996, the change in relative demand for skilled workers was slightly negative overall. ${ }^{20}$ For men, the change was essentially zero, but for women, demand dropped by about one percent. This outcome is consistent with, and provides context to, what I observed in Tables 2 through 4. Wages increased for the higher-skilled women, but increased by more for lower-skilled women, thereby closing the relative earnings gap. Employment followed a similar pattern. If relative demand for higher skilled women had not fallen, then wages would have increased - an outcome incompatible with our data. 
Table 12: Avg Annual Changes in Relative Skilled/Unskilled

\begin{tabular}{|c|l|r|r|r|}
\cline { 5 - 5 } Period & Gender & $\begin{array}{c}\text { Relative } \\
\text { Wage }\end{array}$ & $\begin{array}{c}\text { Relative } \\
\text { Supply }\end{array}$ & $\begin{array}{c}\text { Relative } \\
\text { Demand }\end{array}$ \\
\hline $\mathbf{1 9 9 1 - \mathbf { 9 6 }}$ & Male & $0.3 \%$ & $-0.7 \%$ & $-0.3 \%$ \\
\hline & Female & $-0.6 \%$ & $-0.1 \%$ & $-1.0 \%$ \\
\hline & Total & $0.0 \%$ & $-0.5 \%$ & $-0.5 \%$ \\
\hline & & & & \\
\hline $\mathbf{1 9 9 6 - 0 1}$ & Male & $4.8 \%$ & $-1.0 \%$ & $6.1 \%$ \\
\hline & Female & $3.2 \%$ & $2.7 \%$ & $7.0 \%$ \\
\hline & Total & $3.9 \%$ & $1.1 \%$ & $6.5 \%$ \\
\hline
\end{tabular}

Source: Author's calculations on data from Censuses of Population and Dwellings

In the second half of the decade, the dynamic changed somewhat. Overall, supply increased; for men, relative supply continued to sink, but for women, relative supply shot forward. The crux of the dynamic was the strong increase in demand for both men and women. Because the relative supply of the former continued to retreat, men's relative wage gains were superior to women's. The relative demand for skilled women was significantly greater than the relative demand for skilled men, but because of the increase in relative supply, wage growth lagged a bit behind men's. Importantly, what this points to is demand outstripping supply, or a shortage of skilled workers.

\section{Concluding Remarks}

I had rather modest objectives for this paper; namely, an exposition of the relationship of qualifications and occupations and a discussion of the changing nature of demand for skilled workers. Through this and in addition to the value of such a descriptive analysis, I hoped to shed some light on the idea of skills-shortages. What this analysis showed was that education matters for earnings, but it's not the whole story. Other influences on incomes were apparent: occupation, industry, the incomes of colleagues, and gender. Thus, the labor market doesn't necessarily compensate holders of like qualifications similarly.

In the last part of the paper, I offered a crude model for calculating relative supply of and demand for skilled workers. The objective was to test the assumption of an upskilling New Zealand workforce. What this unsophisticated model showed was that, on balance, relative demand for higher-skilled workers has been on the increase over the past half-decade or so. At face value, more people have higher skills and these skills are in demand by employers - who are willing to pay a wage premium to get what they want. In fact, with demand for skilled workers growing at a stronger rate than their supply, it is reasonable to conclude that there is, at this general level, a skills shortage. Further, from this model, it appeared to be the case that there are differences between the supply and demand factors affecting men and women. Indeed, both relative demand and supply of skilled female workers have grown faster than for skilled male workers.

However interesting these findings are, they are tempered by the limitations of the analysis. Although I restricted the data to the full-time employed aged 24-and-over, there is still much unaccounted-for heterogeneity in the data. For example, as regards the persistence of the gender wage gap, a fuller analysis would incorporate characteristics of both the worker and the workplace. Many domestic and overseas studies have shown that worker characteristics like age, broken careers, specific qualifications, and years of relevant experience, and firm characteristics like size, ownership and export-focus combine to moderate wage gaps between men and women. Also, it would be worth examining the wage effects of the female education bulge (so many women entering the job market with university degrees over a very short period may pull down the average). Finally, the data reported here seem to indicate that issue of genderbased income disparities is much too complicated to distil to a single, pervasive cause.

Regarding a more robust test of demand for skilled workers, it would be worth looking over a longer time horizon. Incorporating several more censuses' worth of data would allow for some interesting comparisons between pre- and post-reforms and the changes in skills acquisition and demand. Of course, the analysis would be greatly aided by using record-level, as opposed to aggregated, data. Yet, census data would not overcome the biggest limitation: The five-yearly census imposes rather arbitrary time-frame. The interesting stuff about changing supply and demand would correlate more closely with the changing structure and cycles of the economy, which don't occur on a 5 -yearly cycle. The alternative of using HLFS could be explored as an alternative.

\section{Notes}

* The views expressed in this paper are those of the author. The paper does not represent the views of the Department of Labour.

${ }^{1}$ Of course, this isn't necessarily true. More university-degreed workers don't necessarily mean that there are more highly skilled workers; it depends upon the actual degree and job. Nevertheless, if more people are getting degrees, then that is, more than likely, a good sign for the economy.

${ }^{2}$ An exposition on the change in formal qualifications sounds reasonable enough. But, it isn't without at least one very large problem: It completely misses skills acquired on the job (both formal and informal). But, I don't feel too constrained by this because I am more concerned with the idea that formal qualifications reflect skill acquisition that could not adequately be addressed through workplace training programs (except at the margin of skills gaps).

${ }^{3}$ The data used here (and in the next section) come from the 1991, 1996, and 2001 censuses. I limit the data to full-time workers, both male and female, over the age of 24 . 
${ }^{4}$ All income data are in 2001 dollars; 1991 earnings are inflated using the CPI.

${ }^{5}$ Qualifications are grouped in the following way: University (Bachelor Degree, Higher Degree); Other Post-Secondary (Basic, Skilled, Intermediate, and Advanced Technical Certificate); High School (6th Form, Higher School Certificate, Other NZ Secondary, and Overseas Secondary); and Fifth-Form or Less (No Qualification and 5th Form Certificate).

\footnotetext{
${ }^{6}$ Note that Total can have higher growth than average of components. This is due, among other reasons, to using median income, as opposed to mean income.
}

${ }^{7}$ As pointed out in fn. 5, the use of median income can lead to the outcome where components of a total income grow faster than total income. Thus, male and female median university incomes grow at a greater rate than total university income, as shown in Table 1.

${ }^{8}$ I mention some of the explanatory variables anon.

${ }^{9}$ Two points need mentioning. First, I acknowledge that the size of the growth is partly due to the level of employment in the base year. Second, and, perhaps, more contentiously, I assume that the labor market for women with university degrees is somewhat distinct from the market for similarly qualified men; this is partly due to employment concentrations in different occupations, but also due to differences in the personal characteristics of female workers compared to male. It is also worth noting that in 2001 the share of full-time employed women with a university degree exceeded the share of full-time employed men with a university degree.

${ }^{10}$ I use as density thresholds the figures of two-thirds and onethird. For 'pure type' occupations, I apply the first standard: In order to be a 'pure type' occupation, at least two-thirds of the incumbents must have one type of qualification. 'Mixed type' occupations result from combinations of qualifications per occupation - each making up between one-third and two-thirds.

${ }^{11}$ Top incomes in the university qualifications are truncated at $\$ 101,000$ because Statistics New Zealand's income bands end at $\$ 101,000$.

${ }^{12}$ It is also true that this representative male (who didn't finish high school) earns more than this representative female university graduate, but because I'm not discussing occupations, that comparison is rather inappropriate.

${ }^{13}$ If anything, it would signal, at least in the nonuniversity occupation classification, that the degree holder is somehow inferior to other potential candidates.

${ }^{14}$ There is quite a bit more to the story of earnings differential than simply education. Nevertheless, that story simply reduces the earnings differential; it does not eliminate it. I speak more of this in the conclusion.

15 The alternative explanation would be that discrimination acts along more a subtle avenue, like through voting preferences. However, second-order explanations, such as this, are often too vague to be convincing - do women, who make up at least one-half of the electorate, act on this purported socially created, pervasive prejudice at the polls?

${ }^{16}$ At this level of specificity, some of the cells could evince the effects of rounding. Under the random rounding process used by Statistics New Zealand, all cell values, including row and column totals, are rounded as follows: zero entries and entries that are already multiples of three are left unchanged, but other cell entries are rounded to the nearest multiple of three.

${ }^{17} \mathrm{I}$ also solved the model using University as the complete set of 'skilled' workers. The outcomes were slightly different (but not contradictory), although less interesting. I use the variable construction steps outlined by Johnson (JEP, Volume 11:2, 1997).

${ }^{18}$ The process is as follows:

Unskilled $=\left(\#\right.$ of employees with $<7^{\text {th }}$

form $) * \frac{\text { (medianwage _ with }<7 \text { thForm })}{\text { (medianwage with } 7 \text { thForm })}$

$+\left(\#\right.$ with $7^{\text {th }}$ Form $)+. \overline{5}$ (\# with Other

Tert)*(medianwage with_OtherTert)

(medianwage with 7thForm)

$\underline{\text { Skilled }}=(\#$ with Univ Qual $)+.5(\# \text { with Other Tert })^{*}$

(medianwage_with_OtherTert)

(medianwage_with_Univ)

${ }^{19}$ For sigma, I use the commonly accepted estimation of 1.5. Other sigma values scale the results.

${ }^{20}$ Given the classification changes affecting Other PostSecondary qualifications, the estimated change in demand or 1991 - 1996 should be looked upon with some scepticism. 